\title{
Prevalence of hepatitis $B$ and $C$ virus infection among leprosy patients in a leprosy-endemic region of central Brazil
}

\author{
José María Hernández Ramos ${ }^{1,2}$, Ágabo Macêdo Costa e Silva ${ }^{3}$, \\ Regina Maria Bringel Martins ${ }^{3}$, Francisco José Dutra Souto ${ }^{1 /+}$ \\ 1Faculdade de Ciências Médicas, Universidade Federal de Mato Grosso, Av. Fernando Correa 2367, 78060-900 Cuiabá, MT, Brasil \\ ${ }^{2}$ Secretaria de Saúde do Município de Várzea Grande, Várzea Grande, MT, Brasil \\ ${ }^{3}$ Instituto de Patologia Tropical e Saúde Pública, Universidade Federal de Goiás, Goiânia, GO, Brasil
}

Leprosy and hepatitis $B$ virus (HBV) are highly endemic in some regions of the state of Mato Grosso, in central Brazil. The association of leprosy with $H B V$ and hepatitis $C$ virus (HCV) was assessed using a seroprevalence study and 191 leprosy outpatients were included. Demographic data and the clinical classification of leprosy were recorded. Evidence of previous HBV infection was present in 53 patients $(27.7 \%$, 95\% confidence interval: $21.9-34.5)$ and two (1\%) were HBsAg positive. Five (2.6\%) had antibodies to HCV. The prevalence of previous exposure to HBV was higher than expected for an adult population in central Brazil. In contrast, the prevalence of anti-HCV antibodies was not much higher regarding the age range of participants. HBV markers were associated with a higher number of sex partners and the use of injections without proper sterilisation of the syringes. The number of HBV carriers was small, suggesting that there was no increased likelihood of chronification among these patients.

Key words: leprosy - epidemiology - prevalence - hepatitis C - hepatitis B - viral hepatitis

Brazil has the second highest prevalence of leprosy in the world (WHO 2010). The state of Mato Grosso (MT) has a leprosy prevalence that is three times higher than that of other Brazilian states. In some regions of MT the incidence is increasing (Magalhães \& Rojas 2005).

Chronic viral hepatitis caused by viruses B (HBV) and $\mathrm{C}(\mathrm{HCV})$ is an important public health problem. These two viruses are responsible for a great proportion of cases of cirrhosis and hepatocellular carcinoma. Some of the HBV hyperendemic areas in Brazil are also located in MT (Souto 2004). The HCV infection prevalence is uniform throughout Brazil, ranging from less than 1-2\% (Fonseca 1999, Nascimento et al. 2008).

Leprosy and viral hepatitis may co-exist in patients from highly endemic areas. It is unknown if injured skin resulting from leprosy may facilitate the spread of bloodborne infectious agents. However, reports such as that by Shiogama et al. (2010) have indicated a progressive increase in the liver-related death rate among inpatients of a Japanese sanatorium and there was a high rate of detection of HCV RNA in liver specimens obtained by necropsy, suggesting that blood-borne hepatitis viruses may circulate at higher rates among these individuals. There are few studies assessing the prevalence of viral hepatitis among leprosy patients in Brazil, but none have been performed in MT (Ottati \& Candeias 1979, Rosa et al. 1992, 1996).

+ Corresponding author: fsouto@terra.com.br

Received 31 December 2010

Accepted 6 June 2011
The aim of this cross-sectional study was to investigate the prevalence of serologic markers of HBV and $\mathrm{HCV}$ in leprosy patients in Várzea Grande, a city with approximately 200,000 inhabitants and one of the highest leprosy prevalence rates in the country.

Patients were selected by consulting of the registry of the Centre for Tropical Diseases, which is the reference centre for the region, between April 2007-January 2009. The patients underwent a structured interview to assess risk factors for viral hepatitis and they had blood samples drawn to perform $\mathrm{HBsAg}$, total anti-HBc, anti-HCV, and anti-HBs tests (Hepanostika Uni-Form for HBsAg and anti-HBc, Hepanostika anti-HCV Ultra, bioMérieux, and Bioelisa anti-HBs, Biokit, respectively).

EpiData software was used to analyse the data (version 3.1). A $p$ value $<0.05$ was considered significant. Logistic regression models were constructed using the variables that had significant associations in the univariate analysis. The protocol of the study was approved by the Ethical Research Board of the University Hospital Julio Muller, Cuiabá, MT (protocol 403/CEP-HUJM/07) and all patients signed informed consent forms.

During the study period, 757 outpatients with leprosy were treated. However, 598 could not be contacted. The lack of contact with these patients was mainly due to changes in address or telephone number. Two patients refused to provide blood samples. Although there was a high number of patients who could not be found, these subjects had gender and age distributions similar to those of the patients who were included. In total, 191 patients were included. The mean age was 48 years (range 18-85) and 109 patients $(56.5 \%)$ were male. One-hundred and eight $(56.3 \%)$ patients had paucibacillary leprosy and 84 (43.7\%) had multibacillary leprosy.

Fifty-three patients $[27.7 \%, 95 \%$ confidence interval (CI): 21.9-34.5] had been exposed to HBV (anti-HBc pos- 
itive). Two (1\%) out of these were HBV carriers (HBsAg positive). Among the 51 anti-HBc-positive/HBsAg-negative subjects, $44(86.3 \%)$ were also anti-HBs positive. Seven (13.7\%) were anti-HBc positive alone. Another 12 $(6.3 \%)$ patients were positive only for anti-HBs, likely as a consequence of previous vaccination. The risk factor frequencies are shown in Table I. The anti-HBc prevalence was higher than that observed in the general adult population of the Central-West Region of Brazil (10.3\%) (Pereira et al. 2009). Rosa et al. (1992) found a higher prevalence of HBV markers (50\%) in institutionalised patients with leprosy in a region near MT (state of Goiás).

\section{TABLE I}

Comparison of the frequency of risk factors between the exposed and non-exposed to hepatitis B virus (HBV) groups

\begin{tabular}{|c|c|c|c|c|}
\hline & $\begin{array}{l}\mathrm{HBV}+ \\
\mathrm{n}(\%)^{a}\end{array}$ & $\begin{array}{l}\mathrm{HBV}- \\
\mathrm{n}(\%)^{a}\end{array}$ & $\begin{array}{c}\text { OR } \\
(95 \% \mathrm{CI})\end{array}$ & $\mathrm{p}$ \\
\hline \multicolumn{5}{|l|}{ Age (years) } \\
\hline $18-30$ & $7(10.4)$ & $31(89.6)$ & 1.0 & $0.01^{b}$ \\
\hline $30-45$ & $10(20.8)$ & $38(79.2)$ & $1.1^{c}$ & - \\
\hline $45-60$ & $15(27.8)$ & $39(72.2)$ & $1.7^{c}$ & - \\
\hline$\geq 60$ & $21(11.4)$ & $30(88.6)$ & $3.1^{c}$ & - \\
\hline \multicolumn{5}{|l|}{ Gender } \\
\hline Female & $19(22.9)$ & $64(77.1)$ & 1.0 & - \\
\hline Male & $34(31.5)$ & $74(68.5)$ & $1.5(0.7-3.1)$ & 0.1 \\
\hline \multicolumn{5}{|l|}{ Clinical form } \\
\hline Paucibacillary & $28(26.2)$ & $79(73.8)$ & $0.8(0.3-2.2)$ & 0.6 \\
\hline Multibacillary & $25(28.9)$ & $59(71.1)$ & 1.0 & - \\
\hline \multicolumn{5}{|l|}{ Surgery } \\
\hline Yes & $30(27.5)$ & $79(72.5)$ & $1.0(0.5-1.9)$ & 0.9 \\
\hline No & $23(28)$ & $59(72)$ & 1.0 & - \\
\hline \multicolumn{5}{|l|}{ Hospital admission } \\
\hline Yes & $25(21.4)$ & $60(78.6)$ & 1.0 & 0.6 \\
\hline No & $28(26.4)$ & $78(73.6)$ & $1.1(0.6-2.1)$ & - \\
\hline \multicolumn{5}{|l|}{ Transfusion } \\
\hline Yes & $8(33.3)$ & $16(66.7)$ & $1.3(0.4-3.3)$ & 0.5 \\
\hline No & $45(20.9)$ & $122(79.1)$ & 1.0 & - \\
\hline \multicolumn{5}{|c|}{ Injectable medications } \\
\hline Yes & $31(28.2)$ & $110(71.8)$ & 1.0 & 0.004 \\
\hline No & $21(40.8)$ & $28(59.2)$ & $2.6(1.2-5.6)$ & - \\
\hline \multicolumn{5}{|l|}{ Usual condom use } \\
\hline Yes & $5(14.1)$ & $26(85.9)$ & 1.0 & 0.1 \\
\hline No & $47(21.7)$ & $111(78.3)$ & $2.2(0.7-6.0)$ & - \\
\hline \multicolumn{5}{|l|}{ Sex partners } \\
\hline 1 & $6(13.6)$ & $38(86.4)$ & 1.0 & $0.03^{b}$ \\
\hline $2-5$ & $21(29.6)$ & $50(70.4)$ & $2.6^{c}$ & - \\
\hline $6-20$ & $17(34.7)$ & $32(65.3)$ & $3.3^{c}$ & - \\
\hline$>20$ & $8(33.3)$ & $16(66.7)$ & $3.1^{c}$ & - \\
\hline
\end{tabular}

$a$ : the sum of all categories of each variable varies due to individual missing information; $b: \mathrm{p}$ value for Chi-square test for trend; $c$ : odds ratio (OR) compared to age group 18-30 (baseline); CI: confidence interval.
In the multivariate analysis, after adjusting for gender and age group, the use of injecting medications and the number of sex partners were significantly associated with HBV infection (Table II). Unprotected sexual intercourse with multiple sex partners is likely the most important source of HBV exposure in the general population from adolescence to adulthood (Kane 1990). These associations suggest that these subjects were likely infected after childhood, which may explain why the rate of HBV chronification in this sample was low.

Some authors have found a higher prevalence of HBsAg in leprosy patients compared to the general population, especially among lepromatous leprosy patients (Kelkar et al. 1973, Ottati \& Candeias 1979). These findings prompted the hypothesis that patients with leprosy would have immunological characteristics that would impair the clearance of HBV. In contrast, there also are studies that have shown conflicting results regarding the association of leprosy and chronic viral hepatitis (Sarno et al. 1980, Fakunle \& Whittle 1981). The heterogeneity of the previous studies partly explains the differing results and prevents us from making definite conclusions.

Because the number of HBV carriers in the present study was low, we cannot conclude if immunosuppression associated with leprosy could facilitate infection with HBV. In this case, it would be expected that immunosuppression also would make chronification more likely, therefore increasing the number of chronically infected HBV subjects. It is more likely that behavioural rather than biological factors facilitated HBV exposure in this patient population.

Five patients were positive for anti-HCV antibodies $(2.6 \%, 95 \%$ CI: 1.1-6.0). No variables were found to be associated with the presence of anti-HCV antibodies. Nascimento et al. (2008) showed a prevalence of anti$\mathrm{HCV}$ antibodies up to $1 \%$ in blood donors of three Brazilian regions. The present study did not have enough

\section{TABLE II}

Multivariate analysis for risk factors for hepatitis B virus (HBV) exposure

\begin{tabular}{lccc}
\hline & OR & $95 \% \mathrm{CI}$ & $\mathrm{p}$ \\
\hline $\begin{array}{l}\text { Injectable medications } \\
\text { Age (years) }\end{array}$ & 2.3 & $1.0-4.9$ & 0.02 \\
$\quad$ 18-30 & 1.0 & - & - \\
31-45 & 1.3 & $0.4-4.0$ & 0.6 \\
46-60 & 1.7 & $0.6-4.9$ & 0.3 \\
$\quad>60$ & 3.1 & $1.1-9.2$ & 0.03 \\
Number of sex partners & & & \\
1 & 1.0 & - & - \\
$2-5$ & 3.4 & $1.1-9.8$ & 0.02 \\
$6-20$ & 3.8 & $1.1-13.2$ & 0.03 \\
$>20$ & 3.3 & $0.8-13.0$ & 0.08 \\
\hline
\end{tabular}

variables were included if they were significantly associated with HBV exposure in univariate analysis. Number of included patients: 188. 
power to draw conclusions about the higher prevalence of $\mathrm{HCV}$ exposure among leprosy patients. In addition, a confirmatory test, such as immunoblotting or polymerase chain reaction, was not available in this study. As a consequence, some of the five anti-HCV positive tests could be false-positives, decreasing the prevalence. Furthermore, this study sample included people who were older than would be expected from a randomly selected Brazilian population sample. It is well-known that $\mathrm{HCV}$ infection is more common among people over 45 years old. Thus, in the study region, HCV infection does not seem to be more common in leprosy patients than in the general population.

In conclusion, the prevalence of $\mathrm{HBV}$ exposure in this sample of leprosy patients was higher than that of the general population in the same region. This higher prevalence was most likely the result of a higher rate of sexual and parenteral exposure. However, the higher prevalence of HBV exposure was not associated with a higher risk of chronic HBV infection, suggesting that there is not an immunological defect that predisposes patients with leprosy to chronic infection. Infection with $\mathrm{HCV}$ was not more frequent than in the general adult Brazilian population.

\section{REFERENCES}

Fakunle YM, Whittle HC 1981. Hepatitis-B virus infection in patients with leprosy: a serological study in a leprosarium in northern $\mathrm{Ni}-$ geria. Trans R Soc Trop Med Hyg 75: 623-625.

Fonseca JC 1999. Epidemiologia da infecção pelo vírus da hepatite C no Brasil. Relatório do Grupo de Estudo da Sociedade Brasileira de Hepatologia. Gastroenterol Endosc Digest 18 (Suppl.): S3-S8.

Kane MA 1990. Transmission of the hepatitis B virus in areas of low endemicity. In P Piot, FE Andrew, Hepatitis B: a sexually transmitted disease in heterosexuals, Elsevier Science Publishers, Amsterdam, p. 9-13.
Kelkar SS, Niphadkar KB, Khare PM, Junnarkar RV 1973. Hepatitis B antigen in a leprosy hospital. Bull World Health Org 48: 555-558.

Magalhães MCC, Rojas LI 2005. Evolución de la endemia de la lepra en Brasil. Rev Bras Epidemiol 8: 342-355.

Nascimento MC, Mayaud P, Sabino EC, Torres KL, Franceschi S 2008. Prevalence of hepatitis B and C serological markers among first-time blood donors in Brazil: a multi-center serosurvey. J Med Virol 80: 53-57.

Ottati S, Candeias JA 1979. Subtipos do antígeno Austrália (HBsAg) em doentes de hanseníase. Rev Saude Publica 13: 366-369.

Pereira LMB, Martelli CMT, Merchan-Hamman E, Montarroyos UR, Braga MC, Lima ML, Cardoso MR, Turchi MD, Costa MA, de Alencar LC, Moreira RC, Figueiredo GM, Ximenes RA, Hepatitis Study Group 2009. Population-based multicentric survey of hepatitis B infection and risk factors among three Brazilian regions. Am J Trop Med Hyg 81: 240-247.

Rosa H, Costa APVF, Ferraz ML, Pedroza S, Andrade ALSS, Martelli CM, Zicker F 1992. Association between leprosy and hepatitis B infection. A survey in Goiânia, central Brazil. Rev Inst Med Trop Sao Paulo 34: 421-426.

Rosa H, Martins R, Vanderborght B 1996. Short report: association between leprosy and hepatitis $\mathrm{C}$ infection: a survey in a region of central Brazil. Am J Trop Med Hyg 55: 22-23.

Sarno EN, Azulay DR, Vieira LM, Quadra AA, Barbosa IV, Azulay RD 1980. Prevalência do antígeno Austrália (HBsAg) em pacientes hansenianos. Rev Assoc Med Bras 26: 391-392.

Shiogama K, Teramoto H, Morita Y, Mizutani Y, Shimomura R, Inada K, Kamahora T, Makino M, Tsutsumi Y 2010. Hepatitis C virus infection in a Japanese leprosy sanatorium for the past 67 years. J Med Virol 82: 556-561.

Souto FJ 2004. Hepatitis B and the human migratory movements in the state of Mato Grosso, Brazil. Rev Soc Bras Med Trop 37 (Suppl 2): 63-68.

WHO - World Health Organization 2010. Global leprosy situation, 2010. Weekly Epidemiol Rec 85: 337-348. 